DOI: 10.19195/2300-7729.35.9

\title{
Oddziały informacji naukowej w polskich uczelniach państwowych: miejsce w strukturze organizacyjnej i zakres działania
}

\section{Wstęp}

Zgodnie z ustawą z dnia 27 lipca 2005 r. Prawo o szkolnictwie wyższym, jednym z podstawowych zadań uczelni wyższej jest „upowszechnianie i pomnażanie osiągnięć nauki, kultury narodowej i techniki, w tym poprzez gromadzenie

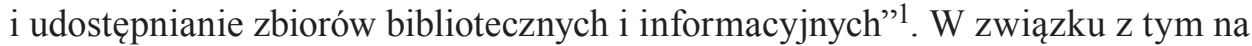
uczelni musi działać system biblioteczno-informacyjny, którego podstawowym elementem jest biblioteka. Struktura organizacyjna, szczegółowe zadania oraz zasady korzystania określane są w statutach poszczególnych uczelni.

W artykule skupiono się wyłącznie na oddziałach informacji naukowej polskich państwowych uczelni wyższych. Przeanalizowano łącznie 94 biblioteki uczelniane, podzielone na 10 grup, w zależności od profilu instytucji macierzystej. Wymieniając w kolejności alfabetycznej, jest to:

- 19 uczelni artystycznych (akademie muzyczne, plastyczne, filmowe),

- 5 uczelni ekonomicznych,

- 11 uczelni medycznych,

- 5 uczelni pedagogicznych,

- 6 uczelni przyrodniczych i rolniczych,

- 18 uczelni technicznych,

- 1 uczelnia teologiczna,

- 5 uczelni wojskowych,

${ }^{1}$ Ustawa z dnia 27 lipca 2005 r. Prawo o szkolnictwie wyższym, Dz.U. 2005, nr 164, poz. 1365. 
- 6 uczelni wychowania fizycznego,

- 18 uniwersytetów.

Zarówno wykaz bibliotek z podziałem na specjalizacje, stanowiący załącznik nr 1 do artykułu, jak i podział, powstał w oparciu o wykazy znajdujące się na stronach ministerstw, którym podlegają poszczególne uczelnie: Ministerstwo Nauki i Szkolnictwa Wyższego ${ }^{2}$, Ministerstwo Zdrowia ${ }^{3}$, Ministerstwo Kultury i Dziedzictwa Narodowego ${ }^{4}$, Ministerstwo Obrony Narodowej ${ }^{5}$.

$\mathrm{W}$ analizie skupiono się przede wszystkim na dokładnej nazwie i miejscu oddziału informacji naukowej w strukturze organizacyjnej biblioteki, liczbie zatrudnionych pracowników oraz realizowanych zadaniach. Spośród wszystkich przebadanych instytucji w 17 przypadkach w ramach biblioteki uczelnianej nie wydzielono oddziału informacji naukowej. Są to, poza Biblioteką Główną Uniwersytetu Medycznego w Białymstoku oraz Biblioteką Główną Chrześcijańskiej Akademii Teologicznej w Warszawie, biblioteki uczelni artystycznych, spośród których tylko w 5 przypadkach wyodrębniono informację naukową jako osobny dział. W związku $\mathrm{z}$ tym podstawą dalszych badań było 77 bibliotek, zaś brak działu w jedynej bibliotece teologicznej wykluczył całą kategorię, pozostawiając podział na 9 specjalizacji.

Ważnym uzupełnieniem artykułu jest załącznik nr 2, czyli tabela, w której zebrane zostały informacje o nazwie oddziału informacji naukowej, liczbie pracowników oraz źródle, z którego korzystano przy ustalaniu zadań realizowanych przez te oddziały.

\section{Oddziały informacji naukowej — analiza formalna}

\subsection{Nazwa jednostki i miejsce w strukturze}

Z uwagi na znaczne zróżnicowanie struktur organizacyjnych bibliotek, poza samą nazwą oddziału zajmującego się informacją naukową, sprawdzone zostało

${ }^{2}$ Ministerstwo Nauki i Szkolnictwa Wyższego. Wykaz uczelni publicznych nadzorowanych przez ministra właściwego ds. szkolnictwa wyższego - publiczne uczelnie akademickie, http:// www.nauka.gov.pl/uczelnie-publiczne/wykaz-uczelni-publicznych-nadzorowanych-przez-ministra-wlasciwego-ds-szkolnictwa-wyzszego-publiczne-uczelnie-akademickie.html [dostęp: 28.07.2016].

${ }^{3}$ Obwieszczenie Ministra Zdrowia z dnia 8 kwietnia 2014 r. w sprawie wykazu jednostek organizacyjnych podległych lub nadzorowanych przez Ministra Zdrowia, M.P. 2014, poz. 333.

${ }^{4}$ Ministerstwo Kultury i Dziedzictwa Narodowego. Wykaz uczelni artystycznych, http:// www.mkidn.gov.pl/pages/strona-glowna/uczniowie-i-studenci/uczelnie-artystyczne/wykaz-uczelni-artystycznych.php [dostęp: 28.07.2016].

${ }^{5}$ Decyzja nr 63/MON Ministra Obrony Narodowej z dnia 24 marca 2016 r. w sprawie wykazu jednostek organizacyjnych podległych Ministrowi Obrony Narodowej lub przez niego nadzorowanych wraz z ich bezpośrednim podporządkowaniem, Dz.U. MON 2016, poz. 38. 
miejsce w schemacie organizacyjnym, wszelkie podległości i ewentualny podział wewnętrzny na jednostki niższego rzędu. W 92,2\% (71 bibliotek) przypadków analizowany dział podlega bezpośrednio dyrektorowi lub jego zastępcy, w 5,2\% informacja naukowa funkcjonuje w ramach większej jednostki ${ }^{6}$, a w 2,6\% ustalenie tego było niemożliwe?

Mimo że dominujące są samodzielne oddziały, ich nazewnictwo pozostaje zróżnicowane. Wszelkie występujące warianty nazw, wraz z liczbą bibliotek, w których się pojawiają, zamieszczono w tabeli 1.

Tabela 1. Nazwy oddziałów informacji naukowej

\begin{tabular}{|r|l|c|}
\hline \multicolumn{1}{|c|}{ Lp. } & \multicolumn{1}{|c|}{ Nazwa } & $\begin{array}{c}\text { Liczba } \\
\text { bibliotek }\end{array}$ \\
\hline 1. & Oddział Informacji Naukowej & 29 \\
\hline 2. & Dział Informacji Naukowej & 3 \\
\hline 3. & Ośrodek Informacji Naukowej & 3 \\
\hline 4. & Oddział Informacji Naukowej i Promocji & 2 \\
\hline 5. & Oddział Informacji Naukowej i Bibliografii & 2 \\
\hline 6. & Sekcja Informacji Naukowo-Technicznej & 2 \\
\hline 7. & Oddział Udostępniania Zbiorów i Informacji Naukowej & 2 \\
\hline 8. & Sekcja Informacji Naukowej & 2 \\
\hline 9. & Informacja Naukowa & 1 \\
\hline 10. & Ośrodek Informacji Naukowej i Bibliograficznej & 1 \\
\hline 11. & Czytelnia i Informacja Naukowa & 1 \\
\hline 12. & Departament Udostępniania Zbiorów i Informacji Naukowej & 1 \\
\hline 13. & Dział Bibliografii i Dokumentacji & 1 \\
\hline 14. & Dział Gromadzenia / Informacja Naukowa & 1 \\
\hline 15. & $\begin{array}{l}\text { Dział Gromadzenia i Opracowania Zbiorów, Informacja Naukowa, In- } \\
\text { formacja Katalogowa }\end{array}$ & 1 \\
\hline 16. & Dział Informacji i Dokumentacji Naukowej & 2 \\
\hline 17. & Dział Informacji Naukowej i Bibliografii & 1 \\
\hline 18. & Dział Informacji Naukowej i Transferu Wiedzy, Czytelnia Czasopism & Bieżących \\
\hline 19. & Dział Informacyjno-Bibliograficzny & 2 \\
\hline
\end{tabular}

${ }^{6}$ Biblioteka Główna Uniwersytetu Humanistyczno-Przyrodniczego w Siedlcach, Biblioteka Jagiellońska Uniwersytetu Jagiellońskiego w Krakowie, Centrum Informacji Naukowej i Biblioteka Uniwersytetu Ekonomicznego w Katowicach, Centrum Wiedzy i Informacji Naukowo-Technicznej Politechniki Wrocławskiej.

${ }^{7}$ Biblioteka Główna Uniwersytetu Przyrodniczego we Wrocławiu, Biblioteka Uniwersytetu Kazimierza Wielkiego w Bydgoszczy. 


\begin{tabular}{|r|l|c|}
\hline 20. & Dział Udostępniania Zbiorów, Informacji i Dokumentacji Naukowej & 1 \\
\hline 21. & Informatorium & 1 \\
\hline 22. & Oddział Informacji i Promocji & 1 \\
\hline 23. & Oddział Informacji i Transferu Wiedzy & 1 \\
\hline 24. & Oddział Informacji Naukowej : Repozytorium UwB & 1 \\
\hline 25. & Oddział Informacji Naukowej i Centrum Dokumentacji Europejskiej & 1 \\
\hline 26. & Oddział Informacji Naukowej i Czasopism & 1 \\
\hline 27. & Oddział Informacji Naukowej i Czytelnia Czasopism & 1 \\
\hline 28. & Oddział Informacji Naukowej i Normalizacyjnej & 1 \\
\hline 29. & Oddział Informacji Naukowej i Obsługi Użytkowników & 1 \\
\hline 30. & Oddział Informacji Naukowej i Prac Naukowo-Dydaktycznych & 1 \\
\hline 31. & Oddział Informacji Naukowej, Szkoleń i Obsługi Użytkowników & 1 \\
\hline 32. & Oddział Informacyjno-Bibliograficzny & 1 \\
\hline 33. & Oddział Promocji i Informacji & 1 \\
\hline 34. & Oddział Udostępniania i Informacji Naukowej & 1 \\
\hline 35. & Oddział Usług Informacyjnych i Szkoleń & 1 \\
\hline 36. & Ośrodek Informacji Naukowej, Bibliograficznej i Patentowej & 1 \\
\hline 37. & Ośrodek Informacji Naukowo-Technicznej & 1 \\
\hline 38. & Samodzielne Stanowisko ds. Bibliografii i Bibliometrii & 1 \\
\hline 39. & Sekcja ds. Bibliometrii, Dokumentacji i Informatyzacji & 1 \\
\hline
\end{tabular}

Wśród 39 różnych nazw dominuje „oddział informacji naukowej”, który wraz z różnymi dopowiedzeniami pojawia się aż 43 razy, co stanowi $55,8 \%$ całości; pozostałe warianty nazw są zdecydowanie mniej popularne. W kilku przypadkach informacja naukowa połączona została z innym działem: udostępniania (4 razy), gromadzenia (2 razy) lub promocji (1 raz). Tylko w 3 przypadkach w nazwie nie występuje określenie ,informacja naukowa” ani inny termin sugerujący obecność usług informacyjnych; o zaliczeniu do grona oddziałów informacji decydowały w tych przypadkach realizowane zadania. Najmniejsze zróżnicowanie nazewnictwa występuje $\mathrm{w}$ grupie bibliotek uczelni technicznych -10 różnych nazw w 18 bibliotekach. W przypadku pozostałych specjalizacji określenia oddziałów informacji właściwie się nie powtarzają. Co ciekawe, nie ma sytuacji, w której $\mathrm{w}$ danej grupie bibliotek o tym samym profilu, żadna z nazw się nie powtarza wszystkie występują tylko raz, zawsze przynajmniej jedna z nich jest wymieniona co najmniej dwukrotnie. 


\subsection{Liczba pracowników}

$\mathrm{Z}$ racji tego, że funkcjonujące oddziały informacji naukowej są w większości samodzielnymi jednostkami organizacyjnymi, mają własnego kierownika oraz wykwalifikowaną kadrę pracowniczą. Liczba pracowników zależy przede wszystkim od wielkości uczelni, co uwarunkowane jest liczbą potencjalnych użytkowników, których potrzeby informacyjne muszą zostać zaspokojone, a także od wielkości biblioteki oraz tego, jakie zadania mają być realizowane przez bibliotekarzy — specjalistów ds. informacji naukowej. Niestety, nie we wszystkich przypadkach udało się ustalić liczbę zatrudnionego personelu. Szczegółowe dane przedstawia wykres 1.

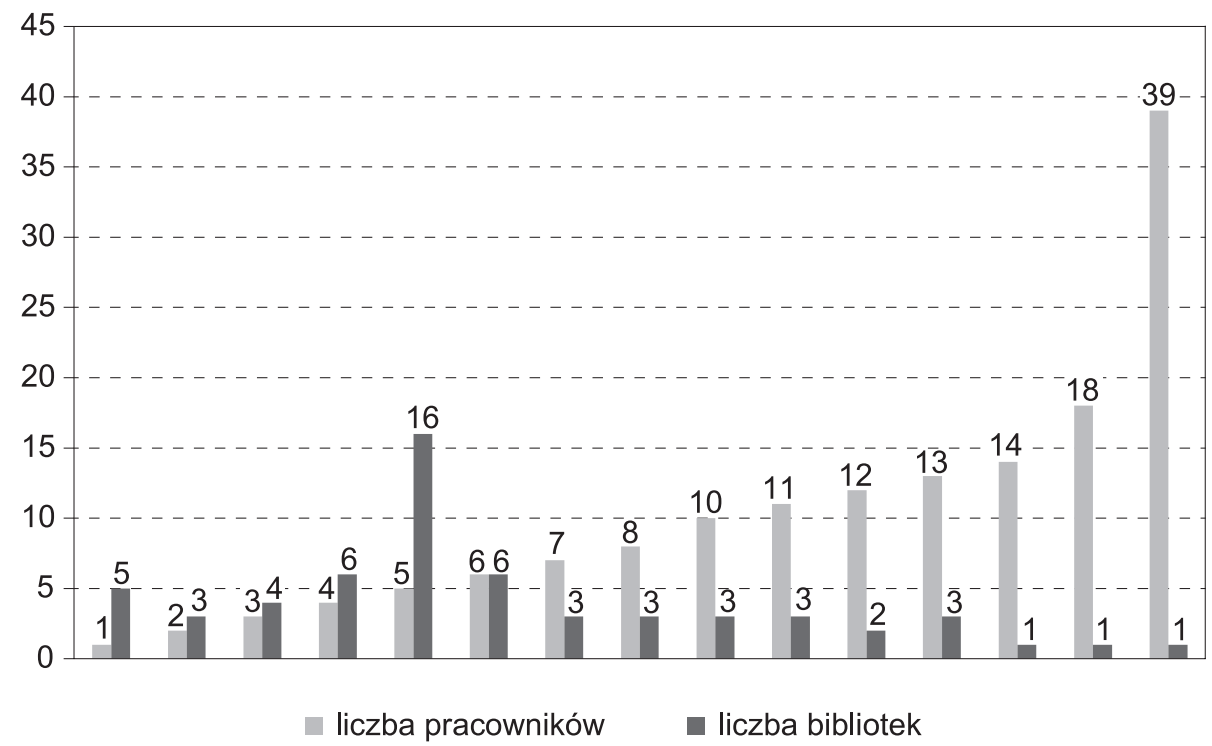

Wykres 1. Liczba pracowników w oddziałach informacji naukowej Źródło: opracowanie własne.

W 17 przypadkach nie udało się ustalić, ilu pracowników liczy oddział informacji naukowej. Natomiast średnia liczba pracowników w pozostałych 60 działach wynosi niemal 7 osób (dokładnie 6,75 etatu), co nie odbiega bardzo od najpopularniejszej w zestawieniu wartości -5 pracowników informacji naukowej w 16 bibliotekach. Najwięcej pracowników — 39 osób — zatrudnionych jest w Centrum Informacji Naukowej i Bibliotece Akademickiej w Katowicach, która jest jednostką wspólną dla Uniwersytetu Śląskiego oraz Uniwersytetu Ekonomicznego w Katowicach ${ }^{8}$, i są to pracownicy Departamentu Udostępniania Zbiorów

\footnotetext{
${ }^{8}$ Poza wymienionym Centrum Uniwersytet Ekonomiczny ma dodatkowo własną bibliotekę.
} 
i Informacji Naukowej. Bardziej szczegółowe określenie liczby bibliotekarzy pracujących tylko w informacji naukowej było niemożliwe. Aż 18 pracowników zatrudnia Oddział Informacji Naukowej Biblioteki Uniwersytetu Wrocławskiego, zaś 14 - Biblioteka Uniwersytetu Warmińsko-Mazurskiego w Olsztynie. Ogólnie to właśnie w bibliotekach uniwersyteckich zatrudnionych jest najwięcej pracowników ds. informacji naukowej, drugie miejsce pod tym względem zajmują biblioteki uczelni technicznych, dalej plasują się medyczne, ekonomiczne, przyrodnicze i rolnicze oraz wychowania fizycznego.

\section{Oddziały informacji naukowej - realizowane zadania}

Liczba bibliotekarzy ściśle związana jest, jak już zostało wspomniane, m.in. z zadaniami, jakie spoczywają na oddziałach informacji naukowej. Informacji o realizowanych zadaniach dostarczyły przede wszystkim statuty oraz regulaminy bibliotek uczelnianych. W przypadku, gdy dotarcie do tych dokumentów było niemożliwe albo nie określono w nich dokładnie zadań oddziału informacji naukowej, sięgano do strony internetowej biblioteki. Niestety w 20 przypadkach nie udało się dotrzeć do informacji na temat realizowanych działań.

Mimo że w tej części badania podstawą było 57 działów informacji naukowej, to znaczne zróżnicowanie w formułowaniu konkretnych zadań sprawiło, że lista wzmianek obejmuje aż 75 pozycji. Aby uporządkować te dane i uniknąć sytuacji, w której ta sama działalność opisywana jest w inny sposób, zdecydowano się ujednolicić nazewnictwo. Dodatkowo połączono niektóre zadania w jeden punkt, tak by zmniejszyć liczbę wymienianych działań, dlatego też w tabeli uwzględniono liczbę wzmianek w wewnętrznych dokumentach uczelnianych lub na stronach www bibliotek, a nie liczbę bibliotek.

Tabela 2. Zadania oddziałów informacji naukowej

\begin{tabular}{|l|c|}
\hline \multicolumn{1}{|c|}{ Zadanie } & $\begin{array}{c}\text { Liczba } \\
\text { wzmianek }\end{array}$ \\
\hline obsługa użytkowników & 52 \\
\hline działalność szkoleniowa & 51 \\
\hline tworzenie, administrowanie oraz testowanie baz danych & 36 \\
\hline $\begin{array}{l}\text { tworzenie zestawień tematycznych / bibliografii, pomoc w ustalaniu danych bi- } \\
\text { bliograficznych }\end{array}$ & 34 \\
\hline działalność dokumentacyjna (głównie dorobek naukowy pracowników uczelni) & 30 \\
\hline $\begin{array}{l}\text { gromadzenie, opracowanie i udostępnianie źródeł informacji, także w formie } \\
\text { tradycyjnej }\end{array}$ & 30 \\
\hline działalność promocyjna / wystawiennicza & 28 \\
\hline
\end{tabular}




\begin{tabular}{|l|c|}
\hline tworzenie analiz bibliometrycznych, w tym analiz cytowań & 26 \\
\hline $\begin{array}{l}\text { gromadzenie, opracowanie i udostępnianie dokumentów normalizacyjnych } \\
\text { i patentowych }\end{array}$ & 23 \\
\hline nadzór nad stroną www oraz profilami bibliotek w mediach społecznościowych & 20 \\
\hline $\begin{array}{l}\text { pomoc w lokalizacji materiałów źródłowych i organizacja wypożyczeń między- } \\
\text { bibliotecznych }\end{array}$ & 17 \\
\hline współpraca z innymi jednostkami uczelni i instytucjami zewnętrznymi & 13 \\
\hline działalność wydawniczo-redakcyjna & 12 \\
\hline realizacja kwerend informacyjnych & 10 \\
\hline sprawozdawczość (zarówno wewnętrzna, jak i zewnętrzna) & 8 \\
\hline prace naukowo-badawcze pracowników, podnoszenie kwalifikacji & 7 \\
\hline obsługa informatyczna systemu bibliotecznego i procesów informacyjnych & 4 \\
\hline pozostałe — charakterystyczne dla danej grupy bibliotek & 22 \\
\hline
\end{tabular}

Niemal każde z wymienionych w tabeli zadań składa się z kilku mniejszych, które niejednokrotnie wymieniane były w regulaminach, sztucznie zwiększając liczbę realizowanych zadań. Jednym z najczęstszych przypadków jest rozbijanie działalności szkoleniowej, m.in. na szkolenia biblioteczne dla studentów I roku, szkolenia indywidualne czy praktyki studenckie i zawodowe. Podobnie sytuacja wygląda w odniesieniu do baz danych - ich testowania, administrowania oraz tworzenia. Uwzględniono w tym punkcie wszelkie wzmianki o tworzonych na uczelni bazach danych (głównie bazy publikacji pracowników oraz bazy specjalistyczne opierające się na zbiorach biblioteki), zewnętrznych bazach, do których pracownicy dodają informacje (m.in. BazEkon, BazTech, NUKAT), a także kontrolowaniu wykorzystania tych źródeł informacji. W przypadku gromadzenia, opracowania i udostępniania źródeł informacji, również w formie tradycyjnej, policzone zostały wszelkie wzmianki o działających czytelniach specjalistycznych (tu m.in. zbiory informacyjne, czasopisma bieżące), opiece nad księgozbiorem informacyjnym, ale i dobór udostępnianych baz danych czy opracowanie informacji o nich. Do punktu dotyczącego tworzenia analiz bibliometrycznych zaliczone zostały też wykonywane analizy cytowań, wszelka pomoc związana ze wskaźnikami bibliometrycznymi - ich wyliczanie, podawanie czy informacja, gdzie można je znaleźć. Tu włączone zostały również wszelkie wzmianki o pomocy w ocenie parametrycznej jednostek. Z kolei prace naukowo-badawcze pracowników oraz podnoszenie kwalifikacji zawierają także organizację i udział w konferencjach naukowych, seminariach lub szkoleniach.

Ostatnią wydzieloną grupą są zadania pozostałe, charakteryzujące biblioteki o jednym profilu lub dla konkretnej jednostki. Wynikają one najczęściej ze specjalizacji biblioteki, jak w przypadku Biblioteki Głównej Śląskiego Uniwersytetu Medycznego, której jednym z zadań realizowanych przez Dział Informacji Na- 
ukowej jest opracowanie i gromadzenie materiałów z zakresu historii medycyny i farmacji na Górnym Śląsku czy Biblioteki Głównej Uniwersytetu Ekonomicznego w Krakowie, gdzie sekcja informacji odpowiada m.in. za tworzenie bibliotek depozytowych Banku Światowego, Międzynarodowego Funduszu Walutowego i Europejskiego Banku Odbudowy i Rozwoju. W tej grupie działań znalazły się również pojawiające się tylko raz: skanowanie dokumentów, wykonywanie kopii materiałów bibliotecznych, współudział w polityce gromadzenia zbiorów czy prowadzenie internetowej księgarni i sprzedaż wydawnictw uniwersytetu. Co ciekawe, Oddział Informacji i Transferu Wiedzy Biblioteki Uniwersytetu w Poznaniu jako jedno ze swoich zadań wymienia pozyskiwanie funduszy zewnętrznych i wyszukiwanie dotacji.

Próba porównania zadań realizowanych przez poszczególne grupy bibliotek uczelnianych pokazała, że w każdym wypadku dominuje obsługa uży tkowników i działalność szkoleniowa (przy czym nie zawsze ujmowane jest prowadzenie praktyk studenckich i zawodowych). Większość działań wymienionych w tabeli występuje - z różną intensywnością — w każdej grupie. Wśród tych, które nie pojawiają się przy każdej specjalizacji, jest tworzenie analiz bibliometrycznych — zarówno biblioteki uczelni pedagogicznych, uczelni wojskowych, uczelni przyrodniczych i rolniczych, jak i uczelni artystycznych tego nie robią. Ponadto Biblioteka Główna Uniwersytetu Technologiczno-Przyrodniczego im. Jana i Jędrzeja Śniadeckich w Bydgoszczy wśród zadań oddziałów informacji naukowej wymienia zlecanie bibliotekom innych uczelni analizy cytowań publikacji pracowników UTP. Także działalność promocyjna i wystawiennicza czy prowadzenie prac naukowo-badawczych pracowników charakterystyczne jest dla bibliotek dużych ośrodków akademickich. Widoczna jest też zależność między liczbą zatrudnionych pracowników a liczbą powierzonych im zadań — im więcej etatów, tym bardziej rozbudowana lista realizowanych zadań.

\section{Podsumowanie}

Analiza obecności oddziałów informacji naukowej działających w ramach bibliotek polskich uczelni wyższych pozwala stwierdzić ich silny związek z profilem całej uczelni oraz wielkością biblioteki. W wypadku małych, wąskospecjalistycznych bibliotek uczelni artystycznych obecność tego działu okazała się w przeważającej większości zbędna. Natomiast we wszystkich przypadkach, gdy dział jest wyodrębniony, jego najważniejszym, podstawowym zadaniem jest obsługa użytkowników, zaspokajanie ich potrzeb informacyjnych udzielaniem informacji bibliograficznych i faktograficznych, a także kompletowanie zasobu informacyjnego dedykowanego potencjalnym użytkownikom. Dodatkowo biblioteki dużych szkół wyższych — przede wszystkim uniwersytetów i uczelni technicznych — realizują 
więcej i bardziej zróżnicowane zadania. Zauważalne jest również podobieństwo realizowanych zadań oraz sposób ich nazywania w ramach poszczególnych grup bibliotek — niemal te same działania realizują pracownicy informacji naukowej, chociażby uczelni medycznych czy wojskowych.

Istnienie działów informacji naukowej oraz wielość i różnorodność ich działalności świadczy niewątpliwie o tym, iż władze uczelni są świadome jak ważne jest zapewnienie obsługi informacyjnej na najwyższym poziomie swoim studentom, doktorantom i pracownikom. Włączanie działów także do spraw ogólnouczelnianych - zdobywanie funduszy, udział w sprawozdawczości, tworzenie materiałów informacyjnych czy prace wydawniczo-redakcyjne — jest dodatkowym potwierdzeniem, że wykwalifikowani bibliotekarze ds. informacji naukowej są elementem koniecznym do realizacji działań statutowych nie tylko biblioteki, lecz całych uczelni.

\section{Bibliografia}

Decyzja nr 63/MON Ministra Obrony Narodowej z dnia 24 marca 2016 r. w sprawie wykazu jednostek organizacyjnych podległych Ministrowi Obrony Narodowej lub przez niego nadzorowanych wraz z ich bezpośrednim podporządkowaniem, Dz.U. MON 2016, poz. 38.

Ministerstwo Kultury i Dziedzictwa Narodowego. Wykaz uczelni artystycznych, http://www. mkidn.gov.pl/pages/strona-glowna/uczniowie-i-studenci/uczelnie-artystyczne/wykaz-uczelni-artystycznych.php [dostęp: 28.07.2016].

Ministerstwo Nauki i Szkolnictwa Wyższego. Wykaz uczelni publicznych nadzorowanych przez ministra właściwego ds. szkolnictwa wyższego — publiczne uczelnie akademickie, http:// www.nauka.gov.pl/uczelnie-publiczne/wykaz-uczelni-publicznych-nadzorowanych-przezministra-wlasciwego-ds-szkolnictwa-wyzszego-publiczne-uczelnie-akademickie.html [dostęp: 28.07.2016].

Obwieszczenie Ministra Zdrowia z dnia 8 kwietnia 2014 r. w sprawie wykazu jednostek organizacyjnych podległych lub nadzorowanych przez Ministra Zdrowia, M.P. 2014, poz. 333.

Ustawa z dnia 27 lipca 2005 r. Prawo o szkolnictwie wyższym, Dz.U. 2005, nr 164, poz. 1365.

\section{Scientific information departaments at Polish Universites: place in the organizational structure and tasks}

Summary

In the article there were analyzed the 94 libraries of state universities, dependent to 4 different ministries. All institutions were divided into 10 groups according to the present profile - the libraries of: economic univeristies, medical univeristies, artistic univeristies, educational univeristies, environmental and agricultural univeristies, technical univeristies, theological univeristies, military univeristies, physical education univeristies and universities. There were examined whether the 
organizational structure have been separated scientific information departments. There were compared the names of 77 scientific information departments discussed in the organizational structure, number of employees and the implementation of tasks. Comparative analysis showed considerable diversity in nomenclature (39 different names), and determine the average number of employees is 7. Among the tasks performed in the first place is provision of information services, followed by training activities and create, administer and testing databases. In addition, there is the relationship between the size and profile of the university and the activities undertaken by employees of scientific information.

KEYWORDS: scientific information, academic libraries, organization of academic libraries, tasks of academic libraries.

\section{Załącznik nr 1}

Wykaz bibliotek państwowych uczelni wyższych w podziale na specjalizacje

\section{Appendix 1}

The list of libraries of state universities divided into specializations

Uczelnie ekonomiczne

1. Biblioteka Główna Uniwersytetu Ekonomicznego we Wrocławiu

2. Biblioteka Główna Uniwersytetu Ekonomicznego w Krakowie

3. Biblioteka Główna Uniwersytetu Ekonomicznego w Poznaniu

4. Biblioteka Szkoły Głównej Handlowej w Warszawie

5. Biblioteka Główna Uniwersytetu Ekonomicznego w Katowicach

Uczelnie medyczne

1. Biblioteka Główna Gdańskiego Uniwersytetu Medycznego

2. Biblioteka Główna Pomorskiego Uniwersytetu Medycznego w Szczecinie

3. Biblioteka Główna Uniwersytetu Medycznego im. Karola Marcinkowskiego w Poznaniu

4. Biblioteka Główna Uniwersytetu Medycznego w Białymstoku

5. Biblioteka Główna Uniwersytetu Medycznego w Lublinie

6. Biblioteka Główna Uniwersytetu Medycznego we Wrocławiu

7. Biblioteka Główna Warszawskiego Uniwersytetu Medycznego

8. Biblioteka Medyczna Collegium Medicum im. Ludwika Rydygiera w Bydgoszczy Uniwersytetu Mikołaja Kopernika w Toruniu

9. Biblioteka Medyczna Collegium Medicum Uniwersytetu Jagiellońskiego w Krakowie

10. Biblioteka Śląskiego Uniwersytetu Medycznego

11. Centrum Informacyjno-Biblioteczne Uniwersytetu Medycznego w Łodzi

Uczelnie artystyczne

1. Biblioteka Akademii Muzycznej im. Feliksa Nowowiejskiego w Bydgoszczy

2. Biblioteka Akademii Muzycznej im. Grażyny i Kiejstuta Bacewiczów w Łodzi

3. Biblioteka Akademii Muzycznej im. Karola Szymanowskiego w Katowicach

4. Biblioteka Akademii Muzycznej im. Stanisława Moniuszki w Gdańsku 


\section{Biblioteka Akademii Muzycznej w Krakowie}

6. Biblioteka Akademii Sztuk Pięknych im. Eugeniusza Gepperta we Wrocławiu

7. Biblioteka Akademii Sztuk Pięknych im. Władysława Strzemińskiego w Łodzi

8. Biblioteka Akademii Sztuk Pięknych w Gdańsku

9. Biblioteka Akademii Sztuk Pięknych w Katowicach

10. Biblioteka Akademii Teatralnej im. Aleksandra Zelwerowicza w Warszawie

11. Biblioteka Główna Akademii Muzycznej im. Ignacego Jana Paderewskiego w Poznaniu

12. Biblioteka Główna Akademii Muzycznej im. Karola Lipińskiego we Wrocławiu

13. Biblioteka Główna Akademii Sztuk Pięknych im. Jana Matejki w Krakowie

14. Biblioteka Główna Akademii Sztuk Pięknych w Warszawie

15. Biblioteka Główna Uniwersytetu Artystycznego w Poznaniu

16. Biblioteka Główna Uniwersytetu Muzycznego Fryderyka Chopina w Warszawie

17. Biblioteka i Ośrodek Informacji Filmowej Państwowej Wyższej Szkoły Filmowej, Telewizyjnej i Teatralnej im. Leona Schillera w Lodzi

18. Biblioteka Państwowej Wyższej Szkoły Teatralnej im. Ludwika Solskiego w Krakowie

19. Mediateka Akademii Sztuki w Szczecinie

\section{Uczelnie pedagogiczne}

1. Biblioteka Główna Akademii im. Jana Długosza w Częstochowie

2. Biblioteka Główna Akademii Pedagogiki Specjalnej w Warszawie

3. Biblioteka Główna Uniwersytetu Pedagogicznego im. Komisji Edukacji Narodowej w Krakowie

4. Biblioteka Główna Uniwersytetu Przyrodniczo-Humanistycznego w Siedlcach

5. Biblioteka Uczelniana Akademii Pomorskiej w Słupsku

Uczelnie przyrodnicze i rolnicze

1. Biblioteka Główna: Regionalny Ośrodek Rolniczej Informacji Naukowej Uniwersytetu Przyrodniczego w Lublinie

2. Biblioteka Główna i Centrum Informacji Naukowej Uniwersytetu Przyrodniczego w Poznaniu

3. Biblioteka Główna im. Władysława Grabskiego Szkoły Głównej Gospodarstwa Wiejskiego w Warszawie

4. Biblioteka Główna Uniwersytetu Przyrodniczego we Wrocławiu

5. Biblioteka Główna Uniwersytetu Rolniczego im. Hugona Kołłątaja w Krakowie

6. Biblioteka Główna Uniwersytetu Technologiczno-Przyrodniczego im. Jana i Jędrzeja Śniadeckich w Bydgoszczy

Uczelnie techniczne

1. Biblioteka Akademicka Akademii Techniczno-Humanistycznej w Bielsku-Białej

2. Biblioteka Główna Politechniki Warszawskiej

3. Biblioteka Główna Akademii Górniczo-Hutniczej im. Stanisława Staszica w Krakowie

4. Biblioteka Główna Politechniki Częstochowskiej

5. Biblioteka Główna Politechniki Gdańskiej

6. Biblioteka Główna Politechniki Opolskiej

7. Biblioteka Główna Politechniki Śląskiej w Gliwicach

8. Biblioteka Główna Politechniki Świętokrzyskiej w Kielcach

9. Biblioteka Główna Uniwersytetu Technologiczno-Humanistycznego im. Kazimierza Pułaskiego w Radomiu

10. Biblioteka Główna Zachodniopomorskiego Uniwersytetu Technologicznego w Szczecinie

11. Biblioteka Politechniki Białostockiej

12. Biblioteka Politechniki Koszalińskiej 
13. Biblioteka Politechniki Krakowskiej im. Tadeusza Kościuszki

14. Biblioteka Politechniki Łódzkiej

15. Biblioteka Politechniki Lubelskiej

16. Biblioteka Politechniki Poznańskiej

17. Biblioteka Politechniki Rzeszowskiej im. Ignacego Łukasiewicza

18. Centrum Wiedzy i Informacji Naukowo-Technicznej Politechniki Wrocławskiej

Uczelnia teologiczna

1. Biblioteka Główna Chrześcijańskiej Akademii Teologicznej w Warszawie

Uczelnie wojskowe

1. Biblioteka Główna Akademii Marynarki Wojennej im. Bohaterów Westerplatte w Gdyni

2. Biblioteka Główna Akademii Obrony Narodowej w Warszawie

3. Biblioteka Główna Wojskowej Akademii Technicznej im. Jarosława Dąbrowskiego w Warszawie

4. Biblioteka Główna Wyższej Szkoły Oficerskiej Sił Powietrznych w Dęblinie

5. Biblioteka Wyższej Szkoły Oficerskiej Wojsk Lądowych im. Gen. Tadeusza Kościuszki we Wrocławiu

Uczelnie wychowania fizycznego

1. Biblioteka Akademii Wychowania Fizycznego im. Jerzego Kukuczki w Katowicach

2. Biblioteka Główna Akademii Wychowania Fizycznego i Sportu im. Jędrzeja Śniadeckiego w Gdańsku

3. Biblioteka Główna Akademii Wychowania Fizycznego im. Bronisława Czecha w Krakowie

4. Biblioteka Główna Akademii Wychowania Fizycznego im. Eugeniusza Piaseckiego w Poznaniu

5. Biblioteka Główna Akademii Wychowania Fizycznego we Wrocławiu

6. Biblioteka Główna im. Jędrzeja Śniadeckiego Akademii Wychowania Fizycznego Józefa Piłsudskiego w Warszawie

\section{Uniwersytety}

1. Biblioteka Główna Uniwersytetu Gdańskiego

2. Biblioteka Główna Uniwersytetu Opolskiego

3. Biblioteka Główna Uniwersytetu Szczecińskiego

4. Biblioteka Jagiellońska Uniwersytetu Jagiellońskiego w Krakowie

5. Biblioteka Uniwersytecka im. Jerzego Giedroycia Uniwersytetu w Białymstoku

6. Biblioteka Uniwersytetu Jana Kochanowskiego w Kielcach

7. Biblioteka Uniwersytetu Kardynała Stefana Wyszyńskiego w Warszawie

8. Biblioteka Uniwersytetu Kazimierza Wielkiego w Bydgoszczy

9. Biblioteka Uniwersytetu Łódzkiego

10. Biblioteka Uniwersytetu Marii Curie-Skłodowskiej w Lublinie

11. Biblioteka Uniwersytetu Mikołaja Kopernika w Toruniu

12. Biblioteka Uniwersytetu Rzeszowskiego

13. Biblioteka Uniwersytetu w Poznaniu

14. Biblioteka Uniwersytetu Warmińsko-Mazurskiego w Olsztynie

15. Biblioteka Uniwersytetu Warszawskiego

16. Biblioteka Uniwersytetu Wrocławskiego

17. Biblioteka Uniwersytetu Zielonogórskiego

18. Centrum Informacji Naukowej i Biblioteka Akademicka Uniwersytetu Śląskiego w Katowicach 


\section{Załącznik nr 2}

Wykaz bibliotek z oddziałami informacji naukowej

\section{Appendix 2}

The list of libraries with scientific information departments

\begin{tabular}{|c|c|c|c|}
\hline Lp. & Nazwa biblioteki & $\begin{array}{l}\text { Nazwa oddziału } \\
\text { informacji naukowej }\end{array}$ & $\begin{array}{l}\text { Źródło informacji o zadaniach } \\
\text { informacji naukowej }\end{array}$ \\
\hline \multicolumn{4}{|c|}{ uczelnie ekonomiczne } \\
\hline 1. & $\begin{array}{l}\text { Biblioteka Główna Uni- } \\
\text { wersytetu Ekonomicz- } \\
\text { nego we Wrocławiu }\end{array}$ & $\begin{array}{l}\text { Oddział Udostępniania } \\
\text { i Informacji Naukowej }\end{array}$ & brak danych \\
\hline 2. & $\begin{array}{l}\text { Biblioteka Główna Uni- } \\
\text { wersytetu Ekonomicz- } \\
\text { nego w Krakowie }\end{array}$ & $\begin{array}{l}\text { Oddział Informacji } \\
\text { Naukowej }\end{array}$ & $\begin{array}{l}\text { Regulamin organizacyjny systemu } \\
\text { biblioteczno-informacyjnego Uni- } \\
\text { wersytetu Ekonomicznego w Kra- } \\
\text { kowie, http://kangur.uek.krakow.pl/ } \\
\text { dokumenty/regulamin_organiza- } \\
\text { cyjny.pdf [dostęp: } 29.07 .2016 \text { ]. }\end{array}$ \\
\hline 3. & $\begin{array}{l}\text { Biblioteka Główna Uni- } \\
\text { wersytetu Ekonomicz- } \\
\text { nego w Poznaniu }\end{array}$ & $\begin{array}{l}\text { Oddział Informacji Na- } \\
\text { ukowej, Szkoleń i Obsługi } \\
\text { Użytkowników }\end{array}$ & $\begin{array}{l}\text { Regulamin organizacyjny Bi- } \\
\text { blioteki Głównej Uniwersytetu } \\
\text { Ekonomicznego w Poznaiu, http:// } \\
\text { www.biblioteka.ue.poznan.pl/page/ } \\
\text { dopobrania/Zarzadzenie_22-2016. } \\
\text { pdf [dostęp: 29.07.2016]. }\end{array}$ \\
\hline 4. & $\begin{array}{l}\text { Biblioteka Szkoły } \\
\text { Głównej Handlowej } \\
\text { w Warszawie }\end{array}$ & $\begin{array}{l}\text { Oddział Informacji } \\
\text { Naukowej i Centrum Do- } \\
\text { kumentacji Europejskiej }\end{array}$ & $\begin{array}{l}\text { Regulamin korzystania ze zbiorów } \\
\text { Biblioteki SGH, http://biblioteka. } \\
\text { sgh.waw.pl/pl/biblioteka/regula- } \\
\text { min/Strony/default.aspx [dostęp: } \\
\text { 29.07.2016]. }\end{array}$ \\
\hline 5. & $\begin{array}{l}\text { Centrum Informacji } \\
\text { Naukowej i Biblioteka } \\
\text { Uniwersytetu Ekono- } \\
\text { micznego w Katowicach }\end{array}$ & $\begin{array}{l}\text { Sekcja ds. Bibliometrii, } \\
\text { Dokumentacji i Informa- } \\
\text { tyzacji }\end{array}$ & $\begin{array}{l}\text { Regulamin organizacyjny Bi- } \\
\text { blioteki Głównej Uniwersytetu } \\
\text { Ekonomicznego w Katowicach, } \\
\text { http://bg.ue.katowice.pl/informacje- } \\
\text {-o-bibliotece/regulaminy [dostęp: } \\
\text { 29.07.2016]. }\end{array}$ \\
\hline
\end{tabular}




\begin{tabular}{|c|c|c|c|}
\hline \multicolumn{4}{|c|}{ uczelnie medyczne } \\
\hline 6. & $\begin{array}{l}\text { Biblioteka Główna } \\
\text { Gdańskiego Uniwersy- } \\
\text { tetu Medycznego }\end{array}$ & $\begin{array}{l}\text { Oddział Informacji Na- } \\
\text { ukowej i Promocji }\end{array}$ & $\begin{array}{l}\text { Regulamin organizacyjny systemu } \\
\text { biblioteczno-informacyjnego Gdań- } \\
\text { skiego Uniwersytetu Medycznego, } \\
\text { http://biblioteka.gumed.edu.pl/ } \\
\text { admin/ckfinder/userfiles/files/pdf/ } \\
\text { regulaminy/zal_nr_1_do_z3514_- } \\
\text { Regulamin_Systemu_Biblot_Infor. } \\
\text { pdf [dostęp: 29.07.2016]. }\end{array}$ \\
\hline 7. & $\begin{array}{l}\text { Biblioteka Główna } \\
\text { Pomorskiego Uniwer- } \\
\text { sytetu Medycznego } \\
\text { w Szczecinie }\end{array}$ & $\begin{array}{l}\text { Dział Informacji Nauko- } \\
\text { wej i Bibliografii }\end{array}$ & $\begin{array}{l}\text { Usługi z zakresu informacji } \\
\text { naukowej, https://www.pum.edu. } \\
\text { pl/biblioteka-glowna/uslugi/uslugi- } \\
\text {-z-zakresu-informacji-naukowej } \\
\text { [dostęp: 29.07.2016]. }\end{array}$ \\
\hline 8. & $\begin{array}{l}\text { Biblioteka Główna Uni- } \\
\text { wersytetu Medycznego } \\
\text { im. Karola Marcinkow- } \\
\text { skiego w Poznaniu }\end{array}$ & $\begin{array}{l}\text { Oddział Informacji } \\
\text { Naukowej }\end{array}$ & $\begin{array}{l}\text { Informacja naukowa, http://www. } \\
\text { bg.ump.edu.pl/info/inf-nauk.php? } \\
\text { lang= pol [dostęp: 29.07.2016]. }\end{array}$ \\
\hline 9. & $\begin{array}{l}\text { Biblioteka Główna Uni- } \\
\text { wersytetu Medycznego } \\
\text { w Lublinie }\end{array}$ & $\begin{array}{l}\text { Dział Informacji i Doku- } \\
\text { mentacji Naukowej }\end{array}$ & $\begin{array}{l}\text { Regulamin udostępniania zbiorów } \\
\text { bibliotecznych, http://www.bibliote- } \\
\text { ka.umlub.pl/o-nas/regulamin-bi- } \\
\text { blioteki/ [dostęp: 29.07.2016]. }\end{array}$ \\
\hline 10. & $\begin{array}{l}\text { Biblioteka Główna Uni- } \\
\text { wersytetu Medycznego } \\
\text { we Wrocławiu }\end{array}$ & $\begin{array}{l}\text { Oddział Informacji Na- } \\
\text { ukowej i Bibliografii }\end{array}$ & $\begin{array}{l}\text { Inne: usługi informacyjne, http:// } \\
\text { www.bg.umed.wroc.pl/inne.html } \\
\text { [dostęp: 29.07.2016]. }\end{array}$ \\
\hline 11. & $\begin{array}{l}\text { Biblioteka Główna War- } \\
\text { szawskiego Uniwersyte- } \\
\text { tu Medycznego }\end{array}$ & $\begin{array}{l}\text { Oddział Informacji } \\
\text { Naukowej }\end{array}$ & $\begin{array}{l}\text { Regulamin biblioteki uczelnianej } \\
\text { Warszawskiego Uniwersytetu Me- } \\
\text { dycznego, http://biblioteka.wum. } \\
\text { edu.pl/sites/biblioteka.wum.edu.pl/ } \\
\text { files/regulamin_biblioteki_uczel- } \\
\text { nianej.pdf [dostęp: 29.07.2016]. }\end{array}$ \\
\hline 12. & $\begin{array}{l}\text { Biblioteka Medyczna } \\
\text { Collegium Medicum } \\
\text { im. Ludwika Rydy- } \\
\text { giera w Bydgoszczy } \\
\text { Uniwersytetu Mikołaja } \\
\text { Kopernika w Toruniu }\end{array}$ & $\begin{array}{l}\text { Dział Informacyjno-Bi- } \\
\text { bliograficzny }\end{array}$ & $\begin{array}{l}\text { Dział informacyjno-bibliograficzny, } \\
\text { http://biblio.cm.umk.pl/index. } \\
\text { php?id=101 [dostęp: 29.07.2016]. }\end{array}$ \\
\hline 13. & $\begin{array}{l}\text { Biblioteka Medyczna } \\
\text { Collegium Medicum } \\
\text { Uniwersytetu Jagielloń- } \\
\text { skiego w Krakowie }\end{array}$ & $\begin{array}{l}\text { Oddział Informacji } \\
\text { Naukowej }\end{array}$ & $\begin{array}{l}\text { Wykaz jednostek organizacyjnych } \\
\text { Biblioteki Medycznej i zakresy ich } \\
\text { działalności, http://www.bm.cm. } \\
\text { uj.edu.pl/biblioteka/regulamin\#o- } \\
\text { golne [dostęp: 29.07.2016]. }\end{array}$ \\
\hline
\end{tabular}




\begin{tabular}{|c|c|c|c|}
\hline 14. & $\begin{array}{l}\text { Biblioteka Śląskiego } \\
\text { Uniwersytetu Medycz- } \\
\text { nego }\end{array}$ & $\begin{array}{l}\text { Dział Bibliografii i Doku- } \\
\text { mentacji }\end{array}$ & $\begin{array}{l}\text { Regulamin organizacyjny } \\
\text { Biblioteki Śląskiego Uniwersy- } \\
\text { tetu Medycznego w Katowicach, } \\
\text { http://biblioteka.sum.edu.pl/ } \\
\text { index.php?option=com_con- } \\
\text { tent\&view=article\&id=99\&I- } \\
\text { temid=514\&lang=pl [dostęp: } \\
\text { 29.07.2016]. }\end{array}$ \\
\hline 15. & $\begin{array}{l}\text { Centrum Informacyjno- } \\
\text {-Biblioteczne Uniwer- } \\
\text { sytetu Medycznego } \\
\text { w Łodzi }\end{array}$ & $\begin{array}{l}\text { Oddział Informacji } \\
\text { Naukowej i Obsługi } \\
\text { Użytkowników }\end{array}$ & $\begin{array}{l}\text { Usługi oferowane przez bibliotekę: } \\
\text { usługi informacyjne, http://bg.u- } \\
\text { med.lodz.pl/index.php/usugi.html } \\
\text { [dostęp: 29.07.2016]. }\end{array}$ \\
\hline \multicolumn{4}{|c|}{ uczelnie artystyczne } \\
\hline 16. & $\begin{array}{l}\text { Biblioteka Akade- } \\
\text { mii Muzycznej im. } \\
\text { Stanisława Moniuszki } \\
\text { w Gdańsku }\end{array}$ & Informacja Naukowa & $\begin{array}{l}\text { Informacja naukowa, http://prze- } \\
\text { wodnik.amuz.gda.pl/index.php/ } \\
\text { informacja-naukowa/ [dostęp: } \\
\text { 29.07.2016]. }\end{array}$ \\
\hline 17. & $\begin{array}{l}\text { Biblioteka Główna Aka- } \\
\text { demii Muzycznej im. } \\
\text { Ignacego Jana Paderew- } \\
\text { skiego w Poznaniu }\end{array}$ & $\begin{array}{l}\text { Czytelnia i Informacja } \\
\text { Naukowa }\end{array}$ & brak danych \\
\hline 18. & $\begin{array}{l}\text { Biblioteka Główna } \\
\text { Akademii Muzycznej } \\
\text { im. Karola Lipińskiego } \\
\text { we Wrocławiu }\end{array}$ & $\begin{array}{l}\text { Dział Gromadzenia } \\
\text { i Opracowania Zbiorów, } \\
\text { Informacja Naukowa, } \\
\text { Informacja Katalogowa }\end{array}$ & brak danych \\
\hline 19. & $\begin{array}{l}\text { Mediateka Akademii } \\
\text { Sztuki w Szczecinie }\end{array}$ & $\begin{array}{l}\text { Dział Gromadzenia / } \\
\text { Informacja Naukowa }\end{array}$ & brak danych \\
\hline \multicolumn{4}{|c|}{ uczelnie pedagogiczne } \\
\hline 20. & $\begin{array}{l}\text { Biblioteka Główna Aka- } \\
\text { demii im. Jana Długosza } \\
\text { w Częstochowie }\end{array}$ & $\begin{array}{l}\text { Oddział Informacji Nau- } \\
\text { kowej i Bibliografii }\end{array}$ & brak danych \\
\hline 21. & $\begin{array}{l}\text { Biblioteka Główna Aka- } \\
\text { demii Pedagogiki Spec- } \\
\text { jalnej w Warszawie }\end{array}$ & $\begin{array}{l}\text { Dział Informacji Nau- } \\
\text { kowej }\end{array}$ & brak danych \\
\hline 22. & $\begin{array}{l}\text { Biblioteka Główna Uni- } \\
\text { wersytetu Pedagogiczne- } \\
\text { go im. Komisji Edukacji } \\
\text { Narodowej w Krakowie }\end{array}$ & $\begin{array}{l}\text { Oddział Informacji Nau- } \\
\text { kowej }\end{array}$ & brak danych \\
\hline 23. & $\begin{array}{l}\text { Biblioteka Główna } \\
\text { Uniwersytetu Przyrod- } \\
\text { niczo-Humanistycznego } \\
\text { w Siedlcach }\end{array}$ & $\begin{array}{l}\text { Oddział Informacji Nau- } \\
\text { kowej }\end{array}$ & $\begin{array}{l}\text { Regulamin systemu biblioteczno-in- } \\
\text { formacyjnego Uniwersytetu Przyrod- } \\
\text { niczo-Humanistycznego w Siedlcach, } \\
\text { http://www.bg.uph.edu.pl/images/ } \\
\text { OIN/PDF/regulaminy/2_regulamin_- } \\
\text { systemu.pdf [dostęp: } 29.07 .2016 \text { ]. }\end{array}$ \\
\hline
\end{tabular}




\begin{tabular}{|c|c|c|c|}
\hline 24. & $\begin{array}{l}\text { Biblioteka Uczelniana } \\
\text { Akademii Pomorskiej } \\
\text { w Stupsku }\end{array}$ & $\begin{array}{l}\text { Oddział Informacji Nau- } \\
\text { kowej }\end{array}$ & $\begin{array}{l}\text { Biblioteka Uczelniana: Oddział In- } \\
\text { formacji Naukowej, http://arch.apsl. } \\
\text { edu.pl/biblioteka.php?a=167\#left_s } \\
\text { [dostęp: 29.07.2016]. }\end{array}$ \\
\hline \multicolumn{4}{|c|}{ uczelnie przyrodnicze i rolnicze } \\
\hline 25. & $\begin{array}{l}\text { Biblioteka Główna: } \\
\text { Regionalny Ośrodek } \\
\text { Rolniczej Informacji } \\
\text { Naukowej Uniwersytetu } \\
\text { Przyrodniczego } \\
\text { w Lublinie }\end{array}$ & $\begin{array}{l}\text { Oddział Informacji Nau- } \\
\text { kowej }\end{array}$ & $\begin{array}{l}\text { Regulamin systemu biblioteczno- } \\
\text {-informacyjnego Uniwersytetu Przy- } \\
\text { rodniczego w Lublinie, http://bip. } \\
\text { up.lublin.pl/senat/2011/029/Regula- } \\
\text { minBG.pdf [dostęp: 29.07.2016]. }\end{array}$ \\
\hline 26. & $\begin{array}{l}\text { Biblioteka Główna } \\
\text { i Centrum Informacji } \\
\text { Naukowej Uniwer- } \\
\text { sytetu Przyrodniczego } \\
\text { w Poznaniu }\end{array}$ & $\begin{array}{l}\text { Oddział Informacji Nau- } \\
\text { kowej }\end{array}$ & $\begin{array}{l}\text { Struktura organizacyjna: Oddział } \\
\text { Informacji Naukowej, http://bg.up. } \\
\text { poznan.pl/bg/dzialy/obibliotece/ } \\
\text { struktura/struktura_4.php [dostęp: } \\
29.07 .2016] \text {. }\end{array}$ \\
\hline 27. & $\begin{array}{l}\text { Biblioteka Główna im. } \\
\text { Władysława Grabskiego } \\
\text { Szkoły Głównej Gos- } \\
\text { podarstwa Wiejskiego } \\
\text { w Warszawie }\end{array}$ & $\begin{array}{l}\text { Oddział Informacji Nau- } \\
\text { kowej }\end{array}$ & $\begin{array}{l}\text { Regulamin udostępniania zbiorów } \\
\text { Biblioteki Głównej im. Władysława } \\
\text { Grabskiego Szkoły Głównej Gos- } \\
\text { podarstwa Wiejskiego w Warszawie } \\
\text { obowiązujący od dnia } 29 \text { maja } 2009 \text { r. } \\
\text { na podstawie Zarządzenia Rektora nr } \\
13 \text { z dnia } 29 \text { maja } 2009 \text { r., http://www. } \\
\text { bg.sggw.pl/regulamin.html\#informa- } \\
\text { cyjna [dostęp: 29.07.2016]. }\end{array}$ \\
\hline 28. & $\begin{array}{l}\text { Biblioteka Główna Uni- } \\
\text { wersytetu Przyrodnicze- } \\
\text { go we Wrocławiu }\end{array}$ & $\begin{array}{l}\text { Oddział Informacji Nau- } \\
\text { kowej }\end{array}$ & brak danych \\
\hline 29. & $\begin{array}{l}\text { Biblioteka Główna Uni- } \\
\text { wersytetu Rolniczego } \\
\text { im. Hugona Kołłątaja } \\
\text { w Krakowie }\end{array}$ & $\begin{array}{l}\text { Oddział Informacji Nau- } \\
\text { kowej }\end{array}$ & brak danych \\
\hline 30. & $\begin{array}{l}\text { Biblioteka Główna } \\
\text { Uniwersytetu Techno- } \\
\text { logiczno-Przyrodniczego } \\
\text { im. Jana i Jędrzeja Śnia- } \\
\text { deckich w Bydgoszczy }\end{array}$ & $\begin{array}{l}\text { Dział Informacji Nau- } \\
\text { kowej }\end{array}$ & $\begin{array}{l}\text { Oferta usług: informacja naukowa, } \\
\text { http://bg.utp.edu.pl/ [dostęp: } \\
\text { 29.07.2016]. }\end{array}$ \\
\hline \multicolumn{4}{|c|}{ uczelnie techniczne } \\
\hline 31. & $\begin{array}{l}\text { Biblioteka Akade- } \\
\text { micka Akademii Tech- } \\
\text { niczno-Humanistycznej } \\
\text { w Bielsku-Białej }\end{array}$ & $\begin{array}{l}\text { Samodzielne Stanowisko } \\
\text { ds. Bibliografii i Biblio- } \\
\text { metrii }\end{array}$ & $\begin{array}{l}\text { Regulamin organizacyjny biblioteki } \\
\text { Akademii Techniczno-Humanisty- } \\
\text { cznej w Bielsku-Białej, http://www. } \\
\text { biblioteka.ath.bielsko.pl/images/ } \\
\text { pliki/Regulamin\%20Organizacy- } \\
\text { jny\%20Biblioteki.pdf [dostęp: } \\
\text { 29.07.2016]. }\end{array}$ \\
\hline
\end{tabular}




\begin{tabular}{|c|c|c|c|}
\hline 32. & $\begin{array}{l}\text { Biblioteka Główna Poli- } \\
\text { techniki Warszawskiej }\end{array}$ & $\begin{array}{l}\text { Oddział Informacji Nau- } \\
\text { kowej }\end{array}$ & $\begin{array}{l}\text { Regulamin organizacyjny Biblioteki } \\
\text { Głównej Politechniki Warszawskiej, } \\
\text { http://www.bg.pw.edu.pl/dane/ } \\
\text { biblprawo/regulamin_organizacy- } \\
\text { jny_BGPW_tekst_ujednolicony.pdf } \\
\text { [dostęp: 29.07.2016]. }\end{array}$ \\
\hline 33. & $\begin{array}{l}\text { Biblioteka Główna } \\
\text { Akademii Górniczo-Hut- } \\
\text { niczej im. Stanisława } \\
\text { Staszica w Krakowie }\end{array}$ & $\begin{array}{l}\text { Oddział Informacji Nau- } \\
\text { kowej }\end{array}$ & $\begin{array}{l}\text { Oddział Informacji Naukowej, } \\
\text { http://www.bg.agh.edu.pl/pl/ } \\
\text { OIN\#quicktabs-oin_qt=1 [dostęp: } \\
\text { 29.07.2016]. }\end{array}$ \\
\hline 34. & $\begin{array}{l}\text { Biblioteka Główna Po- } \\
\text { litechniki Częstochows- } \\
\text { kiej }\end{array}$ & $\begin{array}{l}\text { Oddział Informacji Nau- } \\
\text { kowej }\end{array}$ & $\begin{array}{l}\text { Usługi informacyjne, http://www. } \\
\text { bg.pcz.pl/page/us\%C5\%82ugi-infor- } \\
\text { macyjne [dostęp: } 29.07 .2016 \text { ]. }\end{array}$ \\
\hline 35. & $\begin{array}{l}\text { Biblioteka Główna Poli- } \\
\text { techniki Gdańskiej }\end{array}$ & $\begin{array}{l}\text { Sekcja Informacji Nau- } \\
\text { kowo-Technicznej }\end{array}$ & $\begin{array}{l}\text { Regulamin organizacyjny bi- } \\
\text { blioteki uczelnianej Politechniki } \\
\text { Gdańskiej, http://bg.pg.edu.pl/doc- } \\
\text { uments/611754/13471160/ ZR\%20 } \\
\text { 13-2013.pdf [dostęp: 29.07.2016]. }\end{array}$ \\
\hline 36. & $\begin{array}{l}\text { Biblioteka Główna Poli- } \\
\text { techniki Opolskiej }\end{array}$ & $\begin{array}{l}\text { Oddział Informacji Nau- } \\
\text { kowej i Promocji }\end{array}$ & $\begin{array}{l}\text { Regulamin organizacyjny Biblioteki } \\
\text { Głównej Politechniki Opolskiej, } \\
\text { https://bg.po.opole.pl/images/ } \\
\text { stories/biblioteka/dokumenty/ } \\
\text { Reg_org_BGPO_2014.pdf [dostęp: } \\
\text { 29.07.2016]. }\end{array}$ \\
\hline 37. & $\begin{array}{l}\text { Biblioteka Główna Poli- } \\
\text { techniki Śląskiej w Gli- } \\
\text { wicach }\end{array}$ & $\begin{array}{l}\text { Oddział Informacji Nau- } \\
\text { kowej }\end{array}$ & $\begin{array}{l}\text { Oddział Informacji Naukowej, } \\
\text { https://www.polsl.pl/Jednostki/ } \\
\text { RJO1/Strony/Uslugi/Us\%C5\%82u- } \\
\text { giinfornauk.aspx [dostęp: } \\
\text { 29.07.2016]. }\end{array}$ \\
\hline 38. & $\begin{array}{l}\text { Biblioteka Główna Poli- } \\
\text { techniki Świętokrzyskiej } \\
\text { w Kielcach }\end{array}$ & $\begin{array}{l}\text { Oddział Informacji Nau- } \\
\text { kowej i Normalizacyjnej }\end{array}$ & brak danych \\
\hline 39. & $\begin{array}{l}\text { Biblioteka Główna } \\
\text { Uniwersytetu Techno- } \\
\text { logiczno-Humanisty- } \\
\text { cznego im. Kazimierza } \\
\text { Pułaskiego w Radomiu }\end{array}$ & $\begin{array}{l}\text { Oddział Informacji Nau- } \\
\text { kowej }\end{array}$ & $\begin{array}{l}\text { Regulamin Biblioteki Głównej } \\
\text { Uniwersytetu Technologiczno-Hu- } \\
\text { manistycznego im. Kazimierza } \\
\text { Pułaskiego, http://uniwersytetradom. } \\
\text { pl/redirect.php?action=setcatego- } \\
\text { ry\&id=3536 [dostęp: } 29.07 .2016 \text { ]. }\end{array}$ \\
\hline 40. & $\begin{array}{l}\text { Biblioteka Główna } \\
\text { Zachodniopomorskiego } \\
\text { Uniwersytetu Techno- } \\
\text { logicznego w Szczecinie }\end{array}$ & $\begin{array}{l}\text { Oddział Informacji Nau- } \\
\text { kowej }\end{array}$ & $\begin{array}{l}\text { Regulamin organizacyjny Biblioteki } \\
\text { Głównej Zachodniopomorskiego } \\
\text { Uniwersytetu Technologicznego } \\
\text { w Szczecinie, http://www.bg.zut. } \\
\text { edu.pl/uploads/090703zal3_regu- } \\
\text { lamin.pdf [dostęp: 29.07.2016]. }\end{array}$ \\
\hline
\end{tabular}




\begin{tabular}{|c|c|c|c|}
\hline 41. & $\begin{array}{l}\text { Biblioteka Politechniki } \\
\text { Białostockiej }\end{array}$ & $\begin{array}{l}\text { Oddział Informacji Nau- } \\
\text { kowej }\end{array}$ & $\begin{array}{l}\text { Regulamin organizacyjny systemu } \\
\text { biblioteczno-informacyjnego Poli- } \\
\text { techniki Białostockiej, http://bib- } \\
\text { lioteka.pb.edu.p1/sites/default/files/ } \\
\text { doc/regulamin_org_2012-12-04.pdf } \\
\text { [dostęp: 29.07.2016]. }\end{array}$ \\
\hline 42. & $\begin{array}{l}\text { Biblioteka Politechniki } \\
\text { Koszalińskiej }\end{array}$ & $\begin{array}{l}\text { Oddział Udostępniania } \\
\text { Zbiorów i Informacji Nau- } \\
\text { kowej }\end{array}$ & $\begin{array}{l}\text { Regulamin Biblioteki Politechniki } \\
\text { Koszalińskiej, http://biblioteka. } \\
\text { tu.koszalin.pl/joomla/index.php?op- } \\
\text { tion=com_content\&view=arti- } \\
\text { cle\&id=191\&Itemid=119 [dostęp: } \\
\text { 29.07.2016]. }\end{array}$ \\
\hline 43. & $\begin{array}{l}\text { Biblioteka Politechniki } \\
\text { Krakowskiej im. Tade- } \\
\text { usza Kościuszki }\end{array}$ & $\begin{array}{l}\text { Oddział Informacji Nau- } \\
\text { kowej }\end{array}$ & $\begin{array}{l}\text { Regulamin Biblioteki Politechniki } \\
\text { Krakowskiej, http://www.biblos. } \\
\text { pk.edu.pl/uploades/regulaminy/Reg- } \\
\text { ulaminOrganizacyjny.pdf [dostęp: } \\
\text { 29.07.2016]. }\end{array}$ \\
\hline 44. & $\begin{array}{l}\text { Biblioteka Politechniki } \\
\text { Łódzkiej }\end{array}$ & $\begin{array}{l}\text { Oddział Promocji i Infor- } \\
\text { macji }\end{array}$ & brak danych \\
\hline 45. & $\begin{array}{l}\text { Biblioteka Politechniki } \\
\text { Lubelskiej }\end{array}$ & $\begin{array}{l}\text { Ośrodek Informacji Nau- } \\
\text { kowo-Technicznej }\end{array}$ & $\begin{array}{l}\text { Regulamin organizacyjny Biblioteki } \\
\text { Politechniki Lubelskiej, http://www. } \\
\text { pollub.pl/files/4/news/files/3471_- } \\
\text { Zarzadzenie,Nr,R-21-2015.pdf } \\
\text { [dostęp: 29.07.2016]. }\end{array}$ \\
\hline 46. & $\begin{array}{l}\text { Biblioteka Politechniki } \\
\text { Poznańskiej }\end{array}$ & $\begin{array}{l}\text { Oddział Informacji Nau- } \\
\text { kowej }\end{array}$ & brak danych \\
\hline 47. & $\begin{array}{l}\text { Biblioteka Politechniki } \\
\text { Rzeszowskiej im. Ig- } \\
\text { nacego Łukasiewicza }\end{array}$ & $\begin{array}{l}\text { Oddział Informacji Nau- } \\
\text { kowej }\end{array}$ & $\begin{array}{l}\text { Oddział Informacji Nauko- } \\
\text { wej, http://biblio.prz.edu.pl/pl/ } \\
\text { zasady-korzystania/oddzial-in- } \\
\text { formacji-naukowej-oin/ [dostęp: } \\
\text { 29.07.2016]. }\end{array}$ \\
\hline 48. & $\begin{array}{l}\text { Centrum Wiedzy i Infor- } \\
\text { macji Naukowo-Tech- } \\
\text { nicznej Politechniki } \\
\text { Wrocławskiej }\end{array}$ & $\begin{array}{l}\text { Sekcja Informacji Nau- } \\
\text { kowo-Technicznej }\end{array}$ & $\begin{array}{l}\text { Sekcja Informacji Naukowo-Tech- } \\
\text { nicznej, http://www.biblioteka.pwr. } \\
\text { wroc.pl/2184962.dhtml [dostęp: } \\
\text { 29.07.2016]. }\end{array}$ \\
\hline \multicolumn{4}{|c|}{ uczelnie wojskowe } \\
\hline 49. & $\begin{array}{l}\text { Biblioteka Główna } \\
\text { Akademii Marynarki } \\
\text { Wojennej im. Bohaterów } \\
\text { Westerplatte w Gdyni }\end{array}$ & Informatorium & $\begin{array}{l}\text { Informatorium, http://www.bg.amw. } \\
\text { gdynia.pl/informatorium [dostęp: } \\
\text { 29.07.2016]. }\end{array}$ \\
\hline 50. & $\begin{array}{l}\text { Biblioteka Główna } \\
\text { Akademii Obrony Naro- } \\
\text { dowej w Warszawie }\end{array}$ & $\begin{array}{l}\text { Ośrodek Informacji Nau- } \\
\text { kowej i Bibliograficznej }\end{array}$ & $\begin{array}{l}\text { Ośrodek Informacji Naukowej } \\
\text { i Bibliograficznej, http://biblioteka. } \\
\text { aon.edu.pl/struktura.php?str=1\#oinb } \\
\text { [dostęp: 29.07.2016]. }\end{array}$ \\
\hline
\end{tabular}




\begin{tabular}{|c|c|c|c|}
\hline 51. & $\begin{array}{l}\text { Biblioteka Główna } \\
\text { Wojskowej Akademii } \\
\text { Technicznej im. Ja- } \\
\text { rosława Dąbrowskiego } \\
\text { w Warszawie }\end{array}$ & $\begin{array}{l}\text { Oddział Informacji Nau- } \\
\text { kowej }\end{array}$ & brak danych \\
\hline 52. & $\begin{array}{l}\text { Biblioteka Główna } \\
\text { Wyższej Szkoły Oficer- } \\
\text { skiej Sił Powietrznych } \\
\text { w Dęblinie }\end{array}$ & $\begin{array}{l}\text { Ośrodek Informacji Nau- } \\
\text { kowej i Bibliograficznej }\end{array}$ & $\begin{array}{l}\text { Struktura Biblioteki Głównej: } \\
\text { Ośrodek Informacji Naukowej } \\
\text { i Bibliograficznej, http://biblioteka. } \\
\text { wsosp.pl/index.php/pl/struktura.html } \\
\text { [dostęp: 29.07.2016]. }\end{array}$ \\
\hline 53. & $\begin{array}{l}\text { Biblioteka Wyższej } \\
\text { Szkoły Oficerskiej Wo- } \\
\text { jsk Lądowych im. Gen. } \\
\text { Tadeusza Kościuszki we } \\
\text { Wrocławiu }\end{array}$ & $\begin{array}{l}\text { Ośrodek Informacji Nau- } \\
\text { kowej, Bibliograficznej } \\
\text { i Patentowej }\end{array}$ & brak danych \\
\hline \multicolumn{4}{|c|}{ uczelnie wychowania fizycznego } \\
\hline 54. & $\begin{array}{l}\text { Biblioteka Akademii } \\
\text { Wychowania Fizycznego } \\
\text { im. Jerzego Kukuczki } \\
\text { w Katowicach }\end{array}$ & $\begin{array}{l}\text { Dział Udostępniania } \\
\text { Zbiorów, Informacji i Do- } \\
\text { kumentacji Naukowej }\end{array}$ & brak danych \\
\hline 55. & $\begin{array}{l}\text { Biblioteka Główna } \\
\text { Akademii Wychowania } \\
\text { Fizycznego i Sportu im. } \\
\text { Jędrzeja Śniadeckiego } \\
\text { w Gdańsku }\end{array}$ & $\begin{array}{l}\text { Ośrodek Informacji Nau- } \\
\text { kowej }\end{array}$ & $\begin{array}{l}\text { Regulamin Udostępniania Zbiorów } \\
\text { Biblioteki Głównej Akademii } \\
\text { Wychowania Fizycznego i Sportu } \\
\text { w Gdańsku, http://www.bib.awf. } \\
\text { gda.pl/index.php/regulamin-udoste- } \\
\text { pniania-zbiorow.html stęp [dostęp: } \\
\text { 29.07.2016]. }\end{array}$ \\
\hline 56. & $\begin{array}{l}\text { Biblioteka Główna Aka- } \\
\text { demii Wychowania Fizy- } \\
\text { cznego im. Bronisława } \\
\text { Czecha w Krakowie }\end{array}$ & $\begin{array}{l}\text { Oddział Udostępniania } \\
\text { Zbiorów i Informacji Nau- } \\
\text { kowej }\end{array}$ & $\begin{array}{l}\text { Regulamin organizacyjny Biblioteki } \\
\text { Głównej Akademii Wychowania } \\
\text { Fizycznego w Krakowie, http://bib- } \\
\text { lioteka.awf.krakow.pl/attachments/ } \\
\text { article/4/regulaminbiblioteki.pdf } \\
\text { [dostęp: 29.07.2016]. }\end{array}$ \\
\hline 57. & $\begin{array}{l}\text { Biblioteka Główna Aka- } \\
\text { demii Wychowania Fizy- } \\
\text { cznego im. Eugeniusza } \\
\text { Piaseckiego w Poznaniu }\end{array}$ & $\begin{array}{l}\text { Ośrodek Informacji Nau- } \\
\text { kowej }\end{array}$ & $\begin{array}{l}\text { Zasady udostępniania zbiorów } \\
\text { i zakres usług Ośrodka Informacji } \\
\text { Naukowej, http://biblioteka.awf. } \\
\text { poznan.pl/index.php?option=con- } \\
\text { tent\&task=view\&id=26\&Itemid= }=58 \\
\text { [dostęp: } 29.07 .2016 \text { ]. }\end{array}$ \\
\hline 58. & $\begin{array}{l}\text { Biblioteka Główna Aka- } \\
\text { demii Wychowania Fizy- } \\
\text { cznego we Wrocławiu }\end{array}$ & $\begin{array}{l}\text { Ośrodek Informacji Nau- } \\
\text { kowej }\end{array}$ & brak danych \\
\hline
\end{tabular}




\begin{tabular}{|c|c|c|c|}
\hline 59. & $\begin{array}{l}\text { Biblioteka Główna im. } \\
\text { Jędrzeja Śniadeckiego } \\
\text { Akademii Wychowania } \\
\text { Fizycznego Józefa Pił- } \\
\text { sudskiego w Warszawie }\end{array}$ & $\begin{array}{l}\text { Oddział Informacji Nau- } \\
\text { kowej i Czasopism }\end{array}$ & brak danych \\
\hline \multicolumn{4}{|c|}{ uniwersytety } \\
\hline 60. & $\begin{array}{l}\text { Biblioteka Główna Uni- } \\
\text { wersytetu Gdańskiego }\end{array}$ & $\begin{array}{l}\text { Oddział Informacji } \\
\text { i Promocji }\end{array}$ & brak danych \\
\hline 61. & $\begin{array}{l}\text { Biblioteka Główna Uni- } \\
\text { wersytetu Opolskiego }\end{array}$ & $\begin{array}{l}\text { Oddział Informacji } \\
\text { Naukowej }\end{array}$ & brak danych \\
\hline 62. & $\begin{array}{l}\text { Biblioteka Główna } \\
\text { Uniwersytetu Szczeciń- } \\
\text { skiego }\end{array}$ & $\begin{array}{l}\text { Oddział Informacji } \\
\text { Naukowej }\end{array}$ & $\begin{array}{l}\text { Biblioteka Główna — Oddział } \\
\text { Informacji Naukowej, http:// } \\
\text { bg.szczecin.pl/oddzial-informacji- } \\
\text {-naukowej/ [dostęp: 29.07.2016]. }\end{array}$ \\
\hline 63. & $\begin{array}{l}\text { Biblioteka Jagiellońska } \\
\text { Uniwersytetu Jagielloń- } \\
\text { skiego w Krakowie }\end{array}$ & $\begin{array}{l}\text { Sekcja Informacji Na- } \\
\text { ukowej }\end{array}$ & $\begin{array}{l}\text { Oddział Udostępniania Zbiorów } \\
\text { i Informacji Naukowej, http://www. } \\
\text { bj.uj.edu.pl/oddzial-udostepniania- } \\
\text {-zbiorow [dostęp: 29.07.2016] }\end{array}$ \\
\hline 64. & $\begin{array}{l}\text { Biblioteka Uniwer- } \\
\text { sytecka im. Jerzego } \\
\text { Giedroycia Uniwersyte- } \\
\text { tu w Białymstoku }\end{array}$ & $\begin{array}{l}\text { Oddział Informacji } \\
\text { Naukowej: Repozytorium } \\
\text { UwB }\end{array}$ & $\begin{array}{l}\text { Oddział Informacji Naukowej, http:// } \\
\text { bg.uwb.edu.pl/?pid=Dzialalnosc_in- } \\
\text { formacyjna [dostęp: 29.07.2016]. }\end{array}$ \\
\hline 65. & $\begin{array}{l}\text { Biblioteka Uniwersytetu } \\
\text { Jana Kochanowskiego } \\
\text { w Kielcach }\end{array}$ & $\begin{array}{l}\text { Oddział Informacji } \\
\text { Naukowej }\end{array}$ & $\begin{array}{l}\text { Regulamin organizacyjny Biblio- } \\
\text { teki Uniwersyteckiej Uniwersytetu } \\
\text { Jana Kochanowskiego w Kielcach, } \\
\text { http://www.buk.ujk.edu.pl/files/ } \\
\text { regulamin-organizacyjny-buk.pdf } \\
\text { [dostęp: 29.07.2016]. }\end{array}$ \\
\hline 66. & $\begin{array}{l}\text { Biblioteka Uniwersy- } \\
\text { tetu Kardynała Stefana } \\
\text { Wyszyńskiego w War- } \\
\text { szawie }\end{array}$ & $\begin{array}{l}\text { Dział Informacji Nauko- } \\
\text { wej i Transferu Wiedzy, } \\
\text { Czytelnia Czasopism } \\
\text { Bieżących }\end{array}$ & $\begin{array}{l}\text { Dział Informacji Naukowej, } \\
\text { http://www.biblioteka.uksw.edu.pl/ } \\
\text { pl/node/626 [dostęp: 29.07.2016]. }\end{array}$ \\
\hline 67. & $\begin{array}{l}\text { Biblioteka Uniwersytetu } \\
\text { Kazimierza Wielkiego } \\
\text { w Bydgoszczy }\end{array}$ & $\begin{array}{l}\text { Sekcja Informacji Na- } \\
\text { ukowej }\end{array}$ & brak danych \\
\hline 68. & $\begin{array}{l}\text { Biblioteka Uniwersytetu } \\
\text { Łódzkiego }\end{array}$ & $\begin{array}{l}\text { Oddział Informacji Na- } \\
\text { ukowej i Prac Naukowo- } \\
\text {-Dydaktycznych }\end{array}$ & brak danych \\
\hline 69. & $\begin{array}{l}\text { Biblioteka Uniwersytetu } \\
\text { Marii Curie-Skłodow- } \\
\text { skiej w Lublinie }\end{array}$ & $\begin{array}{l}\text { Oddział Informacji } \\
\text { Naukowej }\end{array}$ & $\begin{array}{l}\text { Oddział Informacji Naukowej, } \\
\text { http://www.umcs.pl/pl/oddzial- } \\
\text {-informacji-naukowej.htm [dostęp: } \\
\text { 29.07.2016]. }\end{array}$ \\
\hline
\end{tabular}




\begin{tabular}{|c|c|c|c|}
\hline 70. & $\begin{array}{l}\text { Biblioteka Uniwersytetu } \\
\text { Mikołaja Kopernika } \\
\text { w Toruniu }\end{array}$ & $\begin{array}{l}\text { Oddział Informacyjno- } \\
\text {-Bibliograficzny }\end{array}$ & $\begin{array}{l}\text { Informacja, http://www.bu.umk.pl/ } \\
\text { informacja [dostęp: 29.07.2016]. }\end{array}$ \\
\hline 71. & $\begin{array}{l}\text { Biblioteka Uniwersytetu } \\
\text { Rzeszowskiego }\end{array}$ & Informacja Naukowa & $\begin{array}{l}\text { Usługi, http://bur.ur.edu.pl/uslugi } \\
\text { [dostęp: 29.07.2016]. }\end{array}$ \\
\hline 72. & $\begin{array}{l}\text { Biblioteka Uniwersytetu } \\
\text { w Poznaniu }\end{array}$ & $\begin{array}{l}\text { Oddział Informacji } \\
\text { i Transferu Wiedzy }\end{array}$ & $\begin{array}{l}\text { Oddział Informacji i Transferu } \\
\text { Wiedzy, http://lib.amu.edu.pl/index. } \\
\text { php?option=com_content } \\
\text { \&task=view\&id=1176\&Itemid=45 } \\
\text { [dostęp: } 29.07 .2016 \text { ]. }\end{array}$ \\
\hline 73. & $\begin{array}{l}\text { Biblioteka Uniwersytetu } \\
\text { Warmińsko-Mazurskie- } \\
\text { go w Olsztynie }\end{array}$ & $\begin{array}{l}\text { Oddział Informacji } \\
\text { Naukowej i Czytelnia } \\
\text { Czasopism }\end{array}$ & $\begin{array}{l}\text { Oddział Informacji Naukowej } \\
\text { i Czytelnia Czasopism, http://bu- } \\
\text {.uwm.edu.pl/pl/biblioteka/oddzial- } \\
\text { informacji-naukowej-i-czytelnia- } \\
\text { czasopism [dostęp: 29.07.2016]. }\end{array}$ \\
\hline 74. & $\begin{array}{l}\text { Biblioteka Uniwersytetu } \\
\text { Warszawskiego }\end{array}$ & $\begin{array}{l}\text { Oddział Usług Informa- } \\
\text { cyjnych i Szkoleń }\end{array}$ & $\begin{array}{l}\text { Usługi informacyjne i bibliogra- } \\
\text { ficzne, http://www.buw.uw.edu. } \\
\text { pl/index.php?option=com_conten- } \\
\text { t\&task=blogcategory\&id=55\&Ite- } \\
\text { mid=113 [dostęp: } 29.07 .2016 \text { ]. }\end{array}$ \\
\hline 75. & $\begin{array}{l}\text { Biblioteka Uniwersytetu } \\
\text { Wrocławskiego }\end{array}$ & $\begin{array}{l}\text { Oddział Informacji } \\
\text { Naukowej }\end{array}$ & $\begin{array}{l}\text { Regulamin organizacyjny systemu } \\
\text { biblioteczno-informacyjnego Uni- } \\
\text { wersytetu Wrocławskiego, http:// } \\
\text { www.bu.uni.wroc.pl/sites/default/fi- } \\
\text { les/images/doc/regorg3.pdf [dostęp: } \\
\text { 29.07.2016]. }\end{array}$ \\
\hline 76. & $\begin{array}{l}\text { Biblioteka Uniwersytetu } \\
\text { Zielonogórskiego }\end{array}$ & $\begin{array}{l}\text { Dział Informacji Nauko- } \\
\text { wej }\end{array}$ & $\begin{array}{l}\text { Dział Informacji Naukowej, http:// } \\
\text { www.bu.uz.zgora.pl/index.php/en/ } \\
\text { informacje/struktura/22-struktura- } \\
\text { ooooo/205-dzial-informacji- } \\
\text { naukowej2 [dostęp: 29.07.2016]. }\end{array}$ \\
\hline 77. & $\begin{array}{l}\text { Centrum Informacji } \\
\text { Naukowej i Biblioteka } \\
\text { Akademicka Uniwer- } \\
\text { sytetu Śląskiego w Ka- } \\
\text { towicach }\end{array}$ & $\begin{array}{l}\text { Departament Udostęp- } \\
\text { niania Zbiorów i Infor- } \\
\text { macji Naukowej }\end{array}$ & brak danych \\
\hline
\end{tabular}

